\title{
Blood Flow Characteristics and Tissue Nutrition in Apparently Ischaemic Feet
}

In addition, a small number of patients with limb ischaemia of acute onset were investigated. The results of this study of five acutely ischaemic feet are reported separately from the findings in the 13 apparently ischaemic feet described above.

The studies were conducted in the controlled environment of the surgical laboratory. The same ambient temperature $\left(21.7 \pm 0.4^{\circ} \mathrm{C}\right)$ was maintained during each of the 35 observation periods. The subjects lay comfortably on a couch with both legs exposed. Measurements were not made until the end of a 30-minute period of rest and exposure in the coolish environment. The subjects' feet were therefore considered to be in a basal resting state while the measurements were being made.

Resting total foot blood flow was measured by strain gauge plethysmography (Whitney, 1953). The gauge was positioned to encircle the foot at the instep and was connected through a Wheatstone bridge to a direct-writing recorder (ElemaSchönander Mingograph 34). The venous occlusion cuff was placed round the ankle proximal to the malleoli. The method used to calibrate the strain gauge on the foot and the calculation of blood flow from the initial slope of the recorded tracing was identical with that used in the previously reported studies (McEwan et al., 1970) and a detailed description of the method has also been reported elsewhere (Schraibman and Ledingham, 1969).

The pulse of foot blood flow was recorded by amplifying the baseline signal from the strain gauge. Thus the strain gauge system, though designed to detect changes in foot circumference when the venous return was occluded, was sensitive enough to detect the changes in foot circumference that occurred with

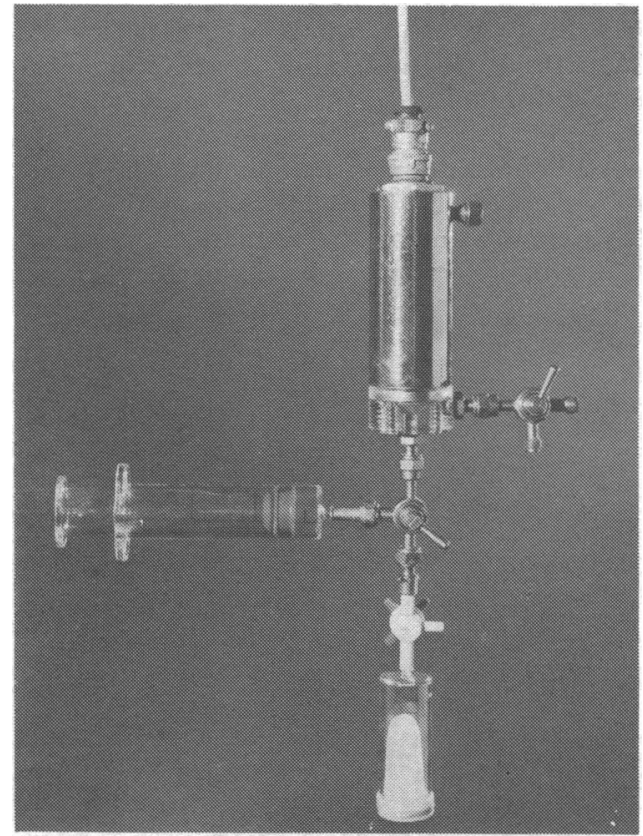
FIG. 1-Water-filled digital volume plethysmograph. The water space between rigid outer shell and flexible inner sleeve is filled from the water
reservoir syringe and bled by the three-way taps connecting with the reservoir syringe and
pressure transducer. 
each pulse wave. In a similar manner the pulse of toe blood flow was detected with a simply constructed digital volume plethysmograph (Fig. 1). The cut-down barrel of a disposable plastic syringe of suitable diameter formed the rigid outer shell and a rubber fingerstall was the flexible inner sleeve. Hydrostatic pressure kept the inner sleeve in contact with the digit and the plethysmograph was connected to the recorder via a pressure transducer (Elema-Schönander EMT33). The second toe and also the index finger were found suitable for digital pulse studies. Regional blood flow pulse (foot, toe, and finger) was investigated in 11 of the 17 normal subjects and in 9 of the 13 ischaemic subjects. Four of the investigated toes of the apparently ischaemic feet had nutritional skin lesions.

Foot skin temperatures were measured from a standard site on the dorsum of the fore foot, distal to the strain gauge, and also from the tip of the great toe with thermocouple applicators and an electric universal thermometer (Ellab, type TE3). Infrared thermography was used in seven normal volunteers and five ischaemic subjects to obtain a temperature-determined radiation map of the foot and leg for display and comparison of blood flow determined skin temperature patterns. Thermovision (Aga) and prototype Thermoscan (EMI Electronics) equipment was used in these studies.

Foot venous blood samples were taken from a suitable vein on the proximal part of the dorsum of the foot, and arterial samples, when taken, came from the brachial or femoral arteries. Two-millilitre aliquots of blood were withdrawn into heparinized syringes by means of a routine anaerobic technique and blood gas estimations performed immediately thereafter. Oxygen tension, carbon dioxide tension, and $\mathrm{pH}$ were measured in a triple electrode system (Radiometer Micro Electrode type AMEI with Oxygen Monitor type PMA 928) calibrated with gases of known concentration and solutions of known $\mathrm{pH}$. Correction of the gas calibration with tonometered blood was not routinely performed. Arterial blood samples were not routinely taken except when the possibility of blood gas abnormalities could not be excluded on clinical grounds in ischaemic subjects. Otherwise it was considered permissible, when arterial oxygen values were required in calculations, to use an assumed value of $95 \mathrm{~mm} \mathrm{Hg}$ for $\mathrm{Po}_{2}$ and $97 \%$ for oxygen saturation (Comroe, Dripps, Dumke, and Denning, 1945).

The following data were derived:

(1) Blood oxygen content $(\mathrm{ml} / 100 \mathrm{ml})=\mathrm{Hb}(\mathrm{g}) \times 1.34 \times$ $\%$ saturation

100

value for blood oxygen content calculated in this way is no different from the value obtained by direct measurement using the Van Slyke technique (Ledingham, McBride, Parratt, and Vance, 1970).

(2) Foot oxygen availability $(\mathrm{ml} / 100 \mathrm{ml} / \mathrm{min})=$ foot blood flow $(\mathrm{ml} / 100 \mathrm{ml} / \mathrm{min}) \times$ arterial oxygen content $(\mathrm{ml} / 100 \mathrm{ml})$.

(3) Foot oxygen extraction $(\%)=100 \times$ arterial oxygen content $(\mathrm{ml} / 100 \mathrm{ml})$-foot venous oxygen content $(\mathrm{ml} / 100 \mathrm{ml}) \div$ arterial oxygen content $(\mathrm{ml} / 100 \mathrm{ml})$.

(4) Foot oxygen consumption $(\mu \mathrm{l} / 100 \mathrm{ml} / \mathrm{min})=$ foot blood flow $(\mathrm{ml} / 100 \mathrm{ml} / \mathrm{min}) \times$ arterial oxygen content $(\mathrm{ml} / 100 \mathrm{ml})-$ foot venous oxygen content $(\mathrm{ml} / 100 \mathrm{ml}) \times 10$.

\section{Results}

Normal foot blood flow was very variable, clothed feet were often quite vasodilated, and random total foot blood flow was invariably higher than in apparently ischaemic feet. When a normal foot was exposed and rested there was usually a pronounced vasoconstriction, particularly in the forefoot and toes. Foot blood flow fell within a few minutes, but owing to the thermal capacity of the tissues the foot skin temperature fell more slowly. About 30 minutes' exposure and rest usually elapsed before a reproducible stable state was achieved. Examples of total foot blood flow and foot and toe pulse records

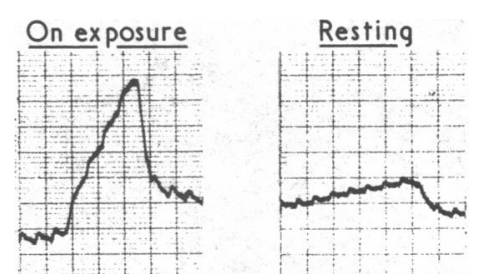

foot blood flow

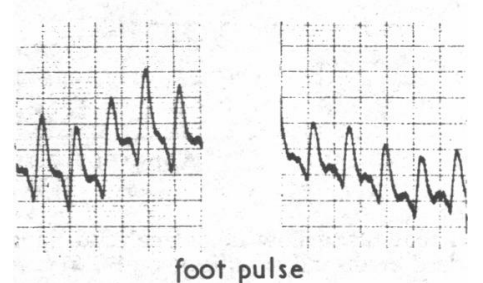

foot pulse

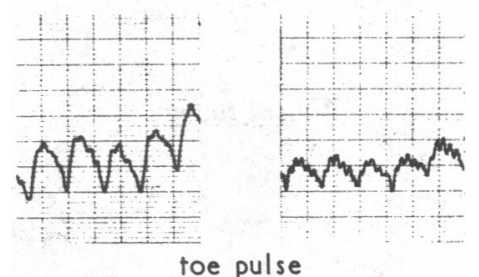

FIG. 2-Effect of 30 minutes' rest and exposure in an ambient temperature of $22.8^{\circ} \mathrm{C}$ on foot blood flow, foot pulse, and toe pulse records in a norma subject. Same signal amplification and same recorder sensitivity in each set of paired records. Fall in mean foot blood flow, 7.5 to $1.2 \mathrm{ml} / 100 \mathrm{ml} / \mathrm{min}$ (slope of record approximately proportional to calculated value); fall in mean foot pulse amplitude, 18 to $12 \mathrm{~mm}$; and fall in mean toe pulse amplitude, 11 to $6 \mathrm{~mm}$.

illustrate these changes (Fig. 2) and foot and toe skin temperatures in the same normal subject are shown in Table I.

TABLE I-Effect of 30 Minutes' Rest and Exposure in an Ambient Temperature of $22 \cdot 8^{\circ} \mathrm{C}$ on Foot Skin Temperature in a Normal Subject

\begin{tabular}{|c|c|c|c|}
\hline & & \multicolumn{2}{|c|}{ Temperature ${ }^{\circ} \mathrm{C}$} \\
\hline & & On Exposure & Resting \\
\hline $\begin{array}{l}\text { Forefoot dorsum } \\
\text { Great toe tip }\end{array}$ & .. & $\begin{array}{l}34 \cdot 2 \\
32 \cdot 3\end{array}$ & $\begin{array}{l}27 \cdot 5 \\
24 \cdot 3\end{array}$ \\
\hline
\end{tabular}

Blood flow in the apparently ischaemic feet was relatively fixed and very little reduction occurred with exposure and rest. The vessels of such feet seemed to be maintained in a state of dilatation largely independent of external factors. Previous studies (McEwan et al., 1970) showed that this dilatation was, however, not maximal. Apparently ischaemic feet did not therefore show a response to exposure and rest in any way comparable to that seen in normal feet. This resulted in their having, when in equivalent basal resting conditions, a total blood flow higher than in normal feet.

Under the basal conditions of the study the mean resting total blood flow in normal feet was $1.28 \pm 0.14 \mathrm{ml} / 100 \mathrm{ml} / \mathrm{min}$ and in apparently ischaemic feet it was $5.88 \pm 1.17 \mathrm{ml} / 100 \mathrm{ml} /$ min (Fig. 3). These values were significantly different.

The pulse of regional blood flow was easily recorded in the foot, toe, and finger of every normal subject studied. The recorded pulse wave form was different at each site, and similar records were obtained from all of these subjects. A typical example is shown in Fig. 4. The pulse of blood flow in the fingers of every ischaemic subject studied was in no way different from normal, but in the apparently ischaemic feet and toes it was always abnormal. Pulse was not detected in three of these apparently ischaemic feet and four of their apparently ischaemic toes. The recorded pulse waves all differed from 


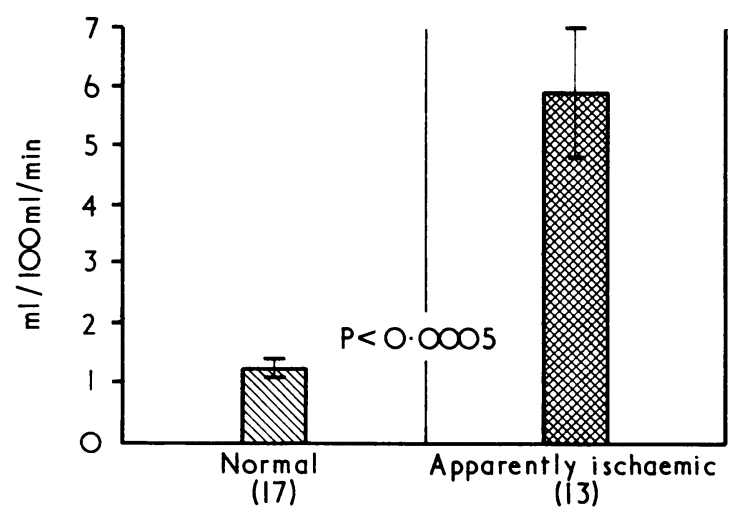

FIG. 3-Resting total foot blood flow in normal and apparently ischaemic feet (mean and standard error and significance of difference).
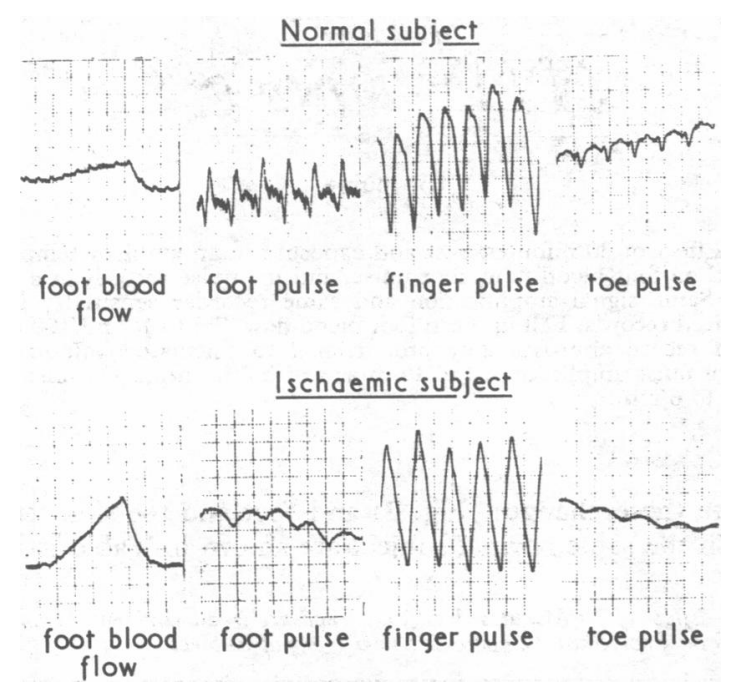

FIG. 4-Resting total foot blood flow records (slope of record approximately proportional to calculated value), and foot, finger, and toe pulse wave
records in representative normal and ischaemic subjects. Same signal amplification and same recorder sensitivity in each set of paired records.

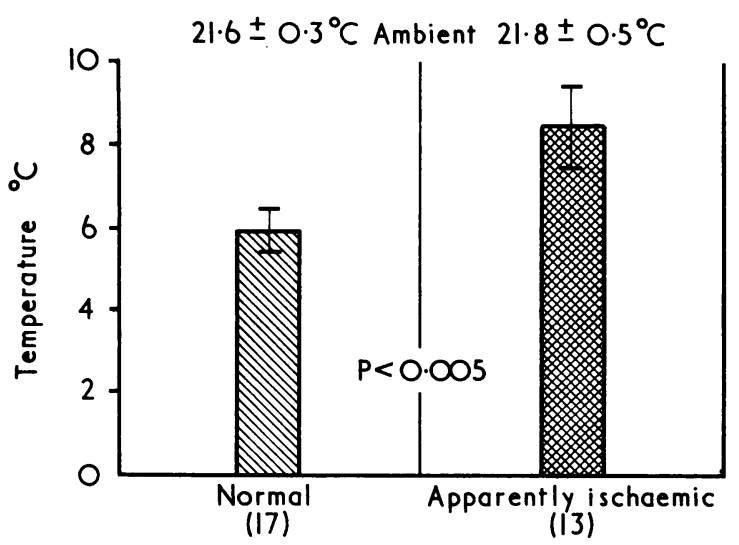

FIG. 5-Skin-ambient temperature difference in normal and apparently ischaemic feet (mean and standard error and significance of difference).

normal in a similar way. The abnormal pulse wave form had a low amplitude, an oblique primary wave with no peak, and no recognizable secondary wave. A pulse was detected in two of the four toes that had nutritional skin lesions. Pulse records from one of these ischaemic subjects are shown in Fig. 4.

In normal subjects the mean forefoot dorsum skin temperature was $27.5 \pm 0.5^{\circ} \mathrm{C}$ and the mean toe skin temperature was $22.7 \pm 0.9^{\circ} \mathrm{C}$, and in the ischaemic subjects the respective mean temperatures were $30.4 \pm 0.6^{\circ} \mathrm{C}$ and $26.4 \pm 0.9^{\circ} \mathrm{C}$ (Table II). These values were significantly different. The difference between the skin temperature and the ambient temperature at the time of each skin temperature measurement was calculated for each foot. The mean forefoot dorsum skinambient temperature difference in normal feet was $5.9 \pm 0.6^{\circ} \mathrm{C}$ and in the ischaemic feet it was $8.6 \pm 0.7^{\circ} \mathrm{C}$ (Fig. 5). These values were significantly different.

TABLE II-Resting Skin Temperature in 17 Normal and 13 Apparently Ischaemic Feet (Mean and Standard Error and Significance of Difference)

\begin{tabular}{|c|c|c|c|}
\hline & \multicolumn{3}{|c|}{ Temperature ${ }^{\circ} \mathrm{C}$} \\
\hline & Dorsum & Toe & Ambient \\
\hline $\begin{array}{l}\text { Normal } \\
\text { Apparently ischaemic } \\
\text { P }\end{array}$ & $\begin{array}{l}27 \cdot 5 \pm 0.5 \\
30 \cdot 4 \pm 0 \cdot 6 \\
<0.0005\end{array}$ & $\begin{array}{l}22 \cdot 7 \pm 0 \cdot 9 \\
26 \cdot 4 \pm 0 \cdot 9 \\
<0.005\end{array}$ & $\begin{array}{l}21.6 \pm 0.3 \\
21.8 \pm 0.5\end{array}$ \\
\hline
\end{tabular}

Foot and leg skin temperature patterns of two normal subjects and one ischaemic subject are displayed in the Thermovision thermograms reproduced in Fig. 6. They show the apparently ischaemic foot warmer than the leg and, in terms of
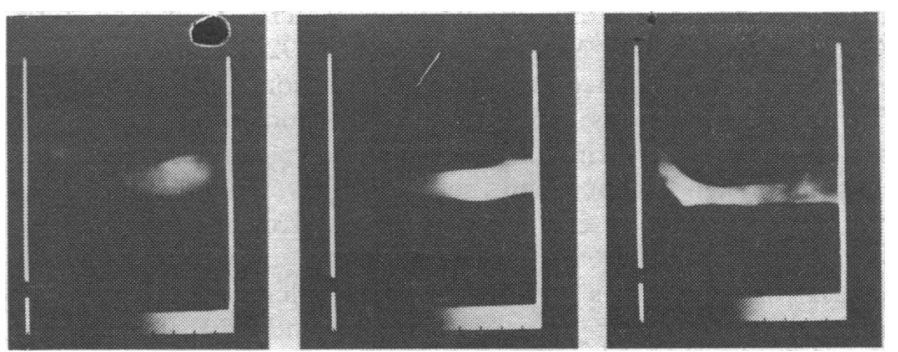

FIG. 6-Thermograms (AGA Thermovision). From left to right, limbs of two normal subjects and one ischaemic subject, showing the normal feet cooler than the legs and the apparently
leg (white areas warmer than black areas).

absolute temperature, warmer than the normal feet, which are seen to be cooler than the normal legs. Thermoscan thermograms (Fig. 7) display skin temperature patterns from both limbs of another ischaemic subject. The conventional thermogram ( $\mathrm{Z}$ mod) of the affected limb shows the relatively high temperature of the apparently ischaemic foot, and one line of this thermogram (A scan) displayed in such a manner that vertical height indicates temperature difference also illustrates this temperature gradient. An A scan display from the thermogram of the other limb (affected by peripheral vascular disease but with no evidence of foot skin ischaemia) shows a different gradient with the foot cooler than the leg.

The mean foot venous oxygen tension $\left(\mathrm{Pvo}_{2}\right)$ was $34.9 \pm 3.0$ $\mathrm{mm} \mathrm{Hg}$ in normal feet and $51.2 \pm 5.6 \mathrm{~mm} \mathrm{Hg}$ in the apparently ischaemic feet (Table III). The mean foot venous carbon dioxide tension $\left(\mathrm{PvCO}_{2}\right)$ was $47 \cdot 6 \pm 2 \cdot 2 \mathrm{~mm} \mathrm{Hg}$ in normal feet

TABLE III-Resting Venous Blood Gas Values in 17 Normal and 13 Apparently Ischaemic Feet (Mean and Standard Error and Significance of Difference)

\begin{tabular}{|c|c|c|c|}
\hline & $\mathrm{Pvo}_{2}(\mathrm{~mm} \mathrm{Hg})$ & $\mathrm{PvCO}_{2}(\mathrm{~mm} \mathrm{Hg})$ & pHv (Units) \\
\hline $\begin{array}{l}\text { Normal } \\
\text { Apparently ischaemic } \\
\mathbf{P} \\
\ldots\end{array}$ & $\begin{array}{c}34.9 \pm 3.0 \\
51.2 \pm 5.6 \\
<0.01\end{array}$ & $\begin{array}{l}47 \cdot 6 \pm 2 \cdot 2 \\
42 \cdot 1 \pm 0.9 \\
<0.025\end{array}$ & $\begin{array}{c}7.328 \pm 0.021 \\
7.379 \pm 0.005 \\
<0.01\end{array}$ \\
\hline
\end{tabular}


and $42.1 \pm 0.9 \mathrm{~mm} \mathrm{Hg}$ in the apparently ischaemic feet, and the mean foot venous $\mathrm{pH}(\mathrm{pHv})$ was $7.328 \pm 0.021$ units in normal feet and 7.379 \pm 0.005 units in the apparently ischaemic feet. These differences were statistically significant.

The mean oxygen availability in normal feet was $25 \pm 2 \mathrm{ml} /$ $100 \mathrm{ml} / \mathrm{min}$ and $122 \pm 39 \mathrm{ml} / 100 \mathrm{ml} / \mathrm{min}$ in the apparently ischaemic feet (Table IV). The mean oxygen extraction in normal feet was $36 \pm 5 \%$ and $21 \pm 5 \%$ in the apparently ischaemic feet, and the mean oxygen consumption in normal feet was $79 \pm 23 \mu \mathrm{l} / 100 \mathrm{ml} / \mathrm{min}$ and $178 \pm 48 \mu \mathrm{l} / 100 \mathrm{ml} / \mathrm{min}$ in the apparently ischaemic feet. These differences were statistically significant.
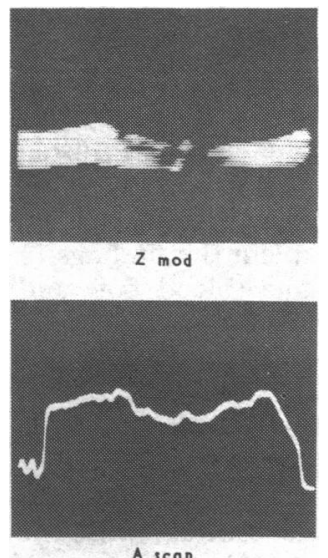

FIG. 7-Thermograms (EMI Thermoscan). Apparently ischaemic foot and leg of an ischaemic subject $(Z$ mod and $A$ scan) and subject's other foot and leg (A scan). White areas warmer than black areas in $\mathrm{Z}$ mod and vertical height of line proportional to temperature difference in $\mathrm{A}$ scan.

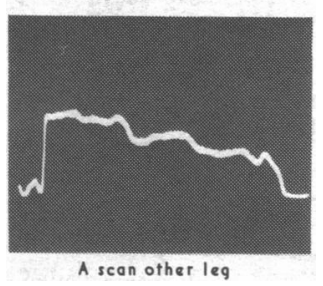
TABLE IV-Resting Oxygen Availability, Extraction, and Consumption in 17 Normal and 13 Apparent
Significance of Difference)

\begin{tabular}{|c|c|c|c|}
\hline & $\begin{array}{c}\text { Oxygen } \\
\text { Availability } \\
(\mathrm{ml} / 100 \mathrm{ml} / \mathrm{min})\end{array}$ & $\begin{array}{c}\text { Oxygen } \\
\text { Extraction } \\
(\%)\end{array}$ & $\begin{array}{c}\text { Oxygen } \\
\text { Consumption } \\
(\mu \mathrm{l} / 100 \mathrm{ml} / \mathrm{min})\end{array}$ \\
\hline $\begin{array}{l}\text { Normal } \\
\text { Apparently ischaemic } \\
\text { P } \\
\quad . .\end{array}$ & $\begin{aligned} & 25 \pm 2 \pm \\
& 122 \pm 39+39 \\
&<0.025\end{aligned}$ & $\begin{array}{r}36 \pm 5 \\
21 \pm 5 \\
<0.05\end{array}$ & $\begin{array}{c}79 \pm 23 \\
178 \pm 48 \\
<0.05\end{array}$ \\
\hline
\end{tabular}

\section{ISCHAEMIA OF ACUTE ONSET}

Blood flow in the acutely ischaemic feet was so low that it was difficult to record. It was also difficult to obtain even the small amounts of foot venous blood required for full blood gas analysis, and emergency surgery had sometimes to be performed before complete examination could be finished. It was therefore not possible to collect, from a sufficient number of feet, data suitable for statistical comparison with the results of the main study.

Investigation of the following illustrative example was technically satisfactory and was performed 18 hours after the onset of acute foot ischaemia following embolic occlusion of the femoral artery. There was mottled cyanosis of the leg and foot and clinically the foot looked beyond spontaneous recovery. Resting total foot blood flow was $0.2 \mathrm{ml} / 100 \mathrm{ml} / \mathrm{min}$ and no pulse was recorded. Forefoot dorsum skin temperature was $24.0^{\circ} \mathrm{C}$ and toe skin temperature was $22 \cdot 2^{\circ} \mathrm{C}$. Foot $\mathrm{Pvo}_{2}$ was $10 \mathrm{~mm} \mathrm{Hg}, \mathrm{PvCO}_{2}$ was $130 \mathrm{~mm} \mathrm{Hg}$, and pHv was 6.800 units. Foot oxygen availability was $3 \mathrm{ml} / 100 \mathrm{ml} / \mathrm{min}$, oxygen extraction was $96 \%$, and oxygen consumption was $32 \mu \mathrm{l} / 100 \mathrm{ml} / \mathrm{min}$.
These results were supported by the combined observations in the remaining four acutely ischaemic feet.

\section{Discussion}

The apparent paradox of a higher-than-normal resting blood flow in clinically ischaemic feet was reported in a previous publication (McEwan et al., 1970). The results of the present investigation have confirmed this earlier report. The laboratory conditions and the characteristics of resting blood flow in the normal foot are described in some detail in order to define clearly the standard reference with which the apparently ischaemic feet have been compared.

Thermometric and thermographic evidence of foot skin temperature differences are presented in support of the foot blood flow measurements. Skin temperature measurements from the normal and the apparently ischaemic feet were made in identical ambient temperatures and thus a true comparison was possible of the differences between foot skin and ambient temperatures in the two groups of subjects. The stable ambient temperatures were lower than the stable foot skin temperatures, and the continuous loss of skin heat to the environment by radiation, convection, and conduction must have been made good by continuous heat gain from the arterial blood (MaxwellCade, 1968). It therefore followed that the greater the skinambient temperature difference the greater the skin blood flow. This expression of the skin temperature and blood flow relationship is more meaningful than simple temperature differences. The temperature difference between leg and foot skin was also investigated. The normal temperature gradient was reduced, abolished, or reversed by the relatively high blood flow in the apparently ischaemic feet. The thermographic illustrations clearly show the reversed gradient in two ischaemic subjects.

The strain gauge plethysmography measurements of total foot blood flow express in quantitive terms the higher-than-normal resting flow in apparently ischaemic feet. It is, however, only an expression of mean volume flow. McDonald (1960) showed that a measurement of mean flow gives information about arterial blood flow that is insufficient for physiological purposes. In every normal physiological situation a blood flow has volume, pressure, and pulse. Pulse is an expression of the periodicity of flow, and there is a flow velocity pulse and a flow volume or pressure pulse. The strain gauge plethysmograph was not designed for pulse studies, and for technical reasons the digital volume plethysmograph had limited capabilities. Nevertheless, both devices detected volume or volume-related changes determined by pulsatile regional blood flow. Pulse waves recorded in the normal subjects were similar to the well-known normal distal arterial volume pulse wave form (McDonald, 1960).

Normal pulsatile flow conducted at pressure through a healthy arterial system with a normal peripheral resistance was characterized by an upright primary wave with a well-defined peak and a subsequent secondary wave seen most clearly in the normal foot pulse record. A parallel relationship between volume pulse wave amplitude and volume blood flow is known to exist in certain circumstances (Burton, 1939), and in this inv'stigation it was found in the normal subjects. However, the relationship which was originally investigated in the presence of normal blood vessels has been uncritically extrapolated to the clinical situation where blood vessels are abnormal, and pulse wave amplitude has been used as a measurement of volume blood flow in peripheral vascular disease (Winsor, Fisher, and Payne, 1959; Eldrup-Jorgensen, Schwartz, and Wallace, 1966). It is well known that resting calf blood flow in claudicants is no lower than normal, but Shepherd (1950) reported the absence of normal pulse characteristics in such regional volume blood flows.

The present investigation has produced substantial evidence for the presence of a higher-than-normal resting volume blood 
flow in apparently ischaemic feet, and this makes it unlikely that the low amplitude of the pulse wave in such feet was simply due to a low-volume blood flow as could have been the case in the presence of a normal arterial system. The pulse wave abnormalities are more likely to have been related to the relatively high volume flow conducted through narrowed and inelastic atherosclerotic arteries and diffusely delivered to the foot at low pressure by collateral channels emptying into abnormally dilated regional vessels with a low peripheral resistance.

Yao, Hobbs, and Irvine (1968), in studies of arterial blood flow velocity pulse by ultrasound, showed that a significant number of leg arteries in patients with peripheral vascular disease had a detectable blood flow though no pulse was clinically palpable. Yao (1970) reported a correlation between the reduced systolic blood pressure in atherosclerotic arteries and the symptoms of peripheral vascular disease. These studies were unfortunately not accompanied by any measurement of mean volume flow.

The proximal arterial disease, the absence of palpable peripheral leg pulses, and the obvious nutritional skin lesions in feet such as were investigated in this present study have in the past been viewed in a purely clinicopathological context. This naturally led to the assumption that foot volume blood flow could only be lower than normal. With time and unchallenged usage the assumption has acquired the status of a proved fact despite the absence in the literature of objective clinical measurements in support of the belief.

The normal leg arterial system has the capacity to deliver to the foot tissues a volume blood flow that is greatly in excess of normal resting tissue requirements. The regional tissue flow is regulated and reduced by the peripheral resistance. It is thereoretically quite possible for a diseased arterial system with a much reduced blood flow capacity, but with a low peripheral resistance, to deliver to the peripheral tissues a resting blood flow that is at least equal to normal in terms of volume but quite abnormal in pressure and pulse.

The total foot blood flow measurements made in this study of apparently ischaemic feet showed that there was no regional ischaemia in any generally accepted sense. A truly ischaemic and therefore hypoxic region would have utilized a high percentage of the oxygen brought to it by its inadequate blood flow and should therefore have had a lower than normal $\mathbf{P v o}_{2}$. Tissue hypoxia and acid base disturbance should have been reflected in high $\mathrm{PvCO}_{2}$ and low pHv levels. The reverse was found and on theoretical grounds alone, the most likely explanation is a higher than normal blood flow.

\section{OXYGEN AVAILABILITY}

Foot oxygen availability as defined in this study was an expression of regional availability of oxygen, and the higher mean value for the apparently ischaemic feet reflected the high measured blood flow in these feet. Foot oxygen extraction was determined entirely by arteriovenous oxygen content differences and the calculation did not include any measured value for blood flow. A direct comparison could therefore be made between foot blood flow and foot oxygen extraction. The low oxygen extraction in the tissues of the apparently ischaemic feet can be satisfactorily explained only by a high blood flowa blood flow so much in excess of the requirements of the bulk of the foot tissues that proportionately less oxygen needed to be extracted than in normal feet. The high oxygen consumption of the apparently ischaemic feet might have appeared paradoxical in view of the low oxygen extraction, but in mathematical terms oxygen consumption is a function of blood flow which was high. This high tissue oxygen consumption may have reflected a higher level of metabolic activity associated with the higher-than-normal blood flow and temperature in apparently ischaemic feet or may have reflected a degree of repair and maintenance activity in tissues precariously balanced between normality and anoxia.

The clinical appearance of the apparently ischaemic feet at the time of examination (generally viable feet with relatively localized lesions) and the results of this objective study could be reconciled by postulating the presence of a perfusion abnormality at tissue level. If normal tissue perfusion required pulse and pressure as well as volume in the regional blood flow a critical imbalance of these essential characteristics occurring at localized sites might therefore be the aetiology of nutritional skin lesions. The relatively high foot blood flow may have been a response to the stimulus of local tissue anoxia (Guyton, Ross, Carrier, and Walker, 1966). Since only volume was influenced by this autoregulatory blood flow adjustment the local perfusion failure was essentially unchanged and the apparently ischaemic feet were therefore as described in this report.

No such hypothesis was necessary to explain the findings in the feet with acute ischaemia. The low total blood flow and $\mathrm{PvO}_{2}$ indicated significant regional ischaemia and tissue hypoxia and the high $\mathrm{PvCO}_{2}$ and low pHv reflected a profound foot tissue acidosis. The oxygen-starved tissues extracted a very high proportion of the inadequately available oxygen and the actual oxygen consumed by the foot was low. These findings were exactly as theoretically expected, with a true regional blood flow insufficiency. So great was the contrast with the results of the investigation of apparently chronically ischaemic feet that the presence of an entirely different pathological process in the latter would seem a reasonable deduction and the suggested hypothesis a reasonable explanation.

The separation of regional volume blood flow and tissue perfusion could be considered a semantic quibble, but the belief that a regional blood flow of normal or higher-than-normal volume must adequately perfuse the tissues is a questionable assumption. The phenomenon of dissociation between volume flow and perfusion is well known in pulmonary pathology. This investigation has produced sufficient evidence to suggest that it may be the cause of chronic nutritional foot skin lesions in atherosclerotic peripheral vascular disease and has suggested a basis for the dissociation.

This work was done while one of us (A. J. McEwan) was in receipt of a Medical Research Council grant for the investigation of treatment of peripheral vascular disease.

\section{References}

Burton, A. C. (1939). American fournal of Physiology, 127, 437.

Comroe, J. M., Dripps, R. D., Dumke, P. R., and Denning, M. (1945) Fournal of the American Medical Association, 128, 710. Eldrup-Jorgensen, S., Schwartz, S. I., and Wallace, J. D. (1966). Surgery, 59,

Guyton, A. C., Ross, J. M., Carrier, O., and Walker, J. R. (1964). Circulation Research, 15, Suppl. No. 1, p. 60.

Ledingham, I. McA., McBride, T. I., Parratt, J. R., and Vance, J. P. (1970). Fournal of Physiology, 210, 87.

McDonald, D. A. (1960). Blood Flow in Arteries. London, Arnold

McEwan, A. J., Stalker, C. G., and Ledingham, I. McA. (1970). British Medical fournal, 3, 612 .

Maxwell-Cade, C. (1968). Radiography, 398, 23.

Schraibman, I. G., and Ledingham, I. McA. (1969). British fournal of Surgery, 56, 295.

Shepherd, J. T. (1950). Clinical Science, 9, 49.

Whitney, R. J. (1953). Fournal of Physiology, 121, 1

Winsor, T., Fisher, E. K., and Payne, J. H. (1959). Fournal of the American Geriatrics Society, 7, 167

Yao, S. T. (1970). British fournal of Surgery, 57, 761.

Yao, S. T., Hobbs, J. T., and Irvine, W. T. (1968). British Medical Fournal, $4,555$. 